\title{
Urgensi Landasan Yuridis-Politis dalam Kebijakan Pendidikan di Indonesia
}

\author{
${ }^{1}$ Bagus Rachmad Saputra, ${ }^{2}$ Darmaji, ${ }^{3}$ Ahmad Supriyanto,${ }^{4}$ Nurul Ulfatin \\ ${ }^{1234}$ Administrasi Pendidikan-Universitas Negeri Malang, \\ * e-mail: ${ }^{1}$ bagusrachmad47@gmail.com, ${ }^{2}$ ajidarmaji64@gmail.com, \\ ${ }^{3}$ a.supriyanto.fip@um.ac.id, ${ }^{4}$ nurul.ulfatin.fip@um.ac.id
}

\begin{abstract}
The writing of this article aims to find out the juridical and political foundations in education, as the basis of the implementation and legitimacy of the implementation of the education policy itself. The juridical-political foundation becomes a strong legal basis in guiding the implementation of education in accordance with the mandate of the law to educate the life of the nation. The writing of this article uses a literature study approach which examines theories that are relevant to the juridical and political foundation in education and policy implementation at the level of the central government, regional government, to the education unit level. The writing of this article can be a reference for the implementation of learning in educational institutions related to educational policies that are based on juridical and political foundations.
\end{abstract}

Keywords: Juridical-political, Educational, Political

\section{PENDAHULUAN}

Pendidikan dalam pelaksanaanya memerlukan sebuah peraturan yang tegas sebagai dasar dan pedoman dalam perumusan kebijakan-kebijakan pendidikan itu sendiri. Jika tidak ada perundang-undangan yang mengikat pelaksanaan pendidikan tidak berjalan sebagaimana mestinya. Selain itu di dalam perundangan-undangan terdapat tujuan yang hendak dicapai dalam pelaksanaan pendidikan itu sendiri. Inilah yang menjadi alasan pentingnya landasan yuridis-politis dalam pendidikan.

Landasan yuridis dan politis nantinya akan menghasilkan kebijakan-kebijakan di bidang pendidikan yang menjadi pedoman penting bagi pelaksanaan pendidikan baik di tingkat birokrasi mulai dari pemerintah pusat, pemerintah provinsi, pemerintah kabupaten atau kota hingga tingkat satuan pendidikan sekolah. Urgensi adanya landasan yuridis itu sendiri untuk mengatur agar setiap kebijakan pendidikan yang dirumuskan bisa berjalan sesuai dengan tujuan yang hendak dicapai dalam sistem pendidikan nasional. Sementara jika berbicara tentang landasan yuridis tentu tidak dapat dilepaskan pada politik.

Landasan yuridis dipengaruhi oleh kebijakan politik dalam implementasinya di tingkat satuan pendidikan. Politik memegang peran kunci dalam aspek perumusan hingga perumusan suatu kebijakan pendidikan karena memiliki legitimasi yang kuat untuk melakukan itu. Oleh karena itu, landasan yuridis dan politis menjadi bagian yang penting dalam penyelenggaraan pendidikan selain secara komprehensif dengan landasan lain seperti landasan filosofi, histori, psikologi, sosiologi, ekonomi, dan antropologi.

\section{PEMBAHASAN}

\section{Landasan Yuridis Pendidikan}

Landasan yuridis dalam pendidikan merupakan suatu sekumpulan perangkat konsep peraturan perundang-undangan dalam bidang pendidikan. Perundang-undangan tersebut menjadi dasar pijakan dari 
penyelenggaraan pendidikan di suatu negara. Landasan yuridis dan politis ini bersifat ideal dan normatif bagi pihak-pihak yang terlibat dalam kegiatan penyelenggaraan pendidikan, sehingga mau tidak mau pihak-pihak yang terlibat dalam proses penyelenggaraan pendidikan harus patuh terhadap perundangundangan yang ada. Meskipun kondisi sosialgeografis tiap daerah berbeda-beda adanya landasan yuridis dalam pendidikan justru mengatur bagaimana kebijakan pendidikan dapat berjalan secara merata.

Landasan yuridis, kebijakan, penyelenggaraan, dan pengembangan dalam bidang pendidikan dapat terhindar dari benturan-benturan kebutuhan pihak-pihak yang terkait dalam penyelenggaraan pendidikan (Aliansar, 2008). Adanya landasan yuridis membuat segala hak dan kewajiban pendidikan setiap peserta didik sebagai input dalam suatu proses pendidikan dapat terpelihara dengan baik.

Telah disinggung sebelumnya bahwa ketika membicarakan tentang landasan yuridis tentu tidak dipisahkan dari politik yang nantinya akan menghasilkan suatu kebijakan. Setiap landasan yuridis dalam wujud peraturan dan perundang-undangan memiliki legitimasi yang kuat karena adanya pengaruh politik dalam implementasi kebijakan di masyarakat. Albertus mengemukakan bahwa setiap kebijakan pemerintah di bidang pendidikan pada umumnya merefleksikan diri pada pandangan tentang masyarakat dan keyakinan politiknya (Lebe, 2015). Sementara Budiarjo melihat dan mencoba memahami dalam politik terdapat lima makna, yakni politik adalah negara, politik adalah kekuasaan, politik adalah pengambilan keputusan, politik adalah kebijaksanaan, dan politik adalah distribusi dan alokasi (Lebe, 2015).

Adanya landasan yuridis-politis dalam pendidikan mempermudah pekerjaan pemerintah dalam mengembangkan aspek kemajuan kualitas pendidikan yang ada. Landasan yuridis-politis dapat menjadi kerangka awal untuk memajukan sistem pendidikan yang ada sehingga hasil yang tentunya diharapkan adalah adanya kerja sama yang baik antara pemerintah dengan penyelenggara pendidikan dengan tujuan penyelengaraan pendidikan dapat semakin maju.

\section{Landasan Yuridis Pendidikan di Indonesia}

Landasan pendidikan di Indonesia atau landasan yuridis pendidikan Indonesia bersumber dari Undang-Undang Nomor 20 Tahun 2003, Pancasila, dan Undang-Undang Dasar (UUD) Negara Republik Indonesia Tahun 1945. Ketiga peraturan dan perundangundangan inilah yang menjadi dasar penting proses penyelenggaraan pendidikan di Indonesia. Landasan yuridis pendidikan di Indonesia diatur dalam UUD RI Tahun 1945 tentang hak dan kewajiban setiap warga negara Indonesia khususnya dalam memperoleh pendidikan. Pasal 31 ayat 1 sampai ayat 5 menekankan bahwa setiap warga negara berhak mendapatkan pendidikan dan pemerintah serta negara mempunyai kewajiban untuk memfasilitasi semua hal yang berhubungan dengan pendidikan (UndangUndang Dasar Negara Republik Indonesia Tahun 1945, n.d.). Selain itu landasan yuridis atau landasan hukum pendidikan di Indonesia adalah Undang-Undang Sistem Pendidikan Nasional (UU Sisdiknas) No 20 Tahun 2003 yang mengatur pendidikan nasional di Indonesia.

Kedudukan sebagai seperangkat dasar hukum, maka landasan yuridis terjabarkan dalam beberapa peraturan dan perundangundangan yang menjabarkan tujuan inti pendidikan nasional yang ada pada Pancasila, UUD 1945, dan UU Sisdiknas No 20 Tahun 2003. Berikut ini adalah sejumlah peraturan dan perundang-undangan yang menjadi titik tolak dalam pelaksanaan pendidikan di Indonesia yakni: (1) UUD 1945 sebagai Landasan Yuridis Pendidikan Indonesia; (2) Pancasila sebagai Landasan Idiil Sistem Pendidikan Indonesia; (3) Ketetapan MPR sebagai landasan yuridis pendidikan nasional; (4) Undang-undang dan peraturan pemerintah sebagai landasan yuridis pendidikan nasional; (5) Keputusan presiden sebagai landasan yuridis pelaksanaan pendidikan nasional; (6) Instruksi menteri sebagai Inndasan yuridis pelaksanaan pendidikan Nasional.

Landasan yuridis pendidikan di Indonesia secara umum diatur oleh beberapa aturan yang telah diuraikan tadi, tujuh 
peraturan tersebut merupakan landasan penting dalam penyelenggaraan pendidikan di Indonesia. Dapat ditarik kesimpulan bahwa landasan yuridis dapat diartikan sebagai seperangkat konsep peraturan dan perundangundangan yang berlaku untuk menjadi titik tolak atau acuan (bersifat material, dan bersifat konseptual) dalam rangka praktek pendidikan dan studi pendidikan. Pentingnya landasan hukum pendidikan adalah dasar atau fondasi perundang-undangan yang menjadi pijakan dan pegangan dalam pelaksanaan pendidikan di suatu negara (Lestari \& Rahmawati., 2012).

\section{Kebijakan Politik dalam Pendidikan}

Kebijakan pokok penyelenggaraan pendidikan yang terdapat dalam UU Sisdiknas 2003 dalam implementasinya memunculkan kebijakan-kebijakan pendidikan. Sebagai contoh, kebijakan wajib belajar sembilan tahun berkonsekuensi adanya kebijakan sekolah gratis bagi peserta didik yang mengikuti program wajib belajar sembilan tahun di Sekolah Dasar (SD) dan Sekolah Menengah Pertama (SMP) yang sempat mengalami perubahan masa wajib belajar pada pergantian era pemerintahan.

Kebijakan sekolah gratis banyak dijadikan jargon dalam kampanye dan tujuantujuan politis menjelang pemilihan umum. Tidak sedikit di antara para calon kepala daerah baik di tingkat kabupaten/kota maupun di tingkat provinsi yang menawarkan sekolah gratis di daerahnya jika mereka dipercaya menjadi kepala daerah tersebut. Bersamaan dengan kebijakan wajib belajar ini pemerintah menganggarkan biaya yang cukup besar untuk mendanai terlaksananya kebijakan wajib belajar dan sekolah gratis. Kebijakan dalam bidang pendanaan pendidikan di sini kemudian dikenal dengan istilah Biaya Operasional Sekolah (BOS).

Dengan dana BOS sekolah dapat menjalankan seluruh kegiatan akademik yang ada di sekolah. Dalam implementasinya, kebijakan BOS ini berjalan dengan baik, meskipun juga ada kelemahan dan kekurangannya. Marzuki dalam penelitiannya mengemukakan secara umum dapat dianalisis bahwa kebijakan pendidikan di Indonesia, terutama yang didasarkan pada Undangundang Sisdiknas 2003 dan peraturan perundang-undangan di bawahnya (PP dan Permendiknas) diarahkan untuk mencapai halhal sebagai berikut: (1) Mengupayakan perluasan dan pemerataan kesempatan memperoleh pendidikan yang bermutu tinggi bagi seluruh rakyat Indonesia menuju terciptanya manusia Indonesia berkualitas tinggi dengan peningkatan anggaran pendidikan secara berarti. Alokasi dana pendidikan 20\% dari APBN dan APBD merupakan rekor tertinggi selama ini; (2) Meningkatkan kemampuan akademik dan profesional serta meningkatkan jaminan kesejahteraan tenaga kependidikan sehingga tenaga pendidik mampu berfungsi secara optimal terutama dalam peningkatan pendidikan watak dan budi pekerti agar dapat mengembalikan wibawa lembaga dan tenaga kependidikan; (3) Melakukan pembaruan dan pemantapan sistem pendidikan nasional berdasarkan prinsip desentralisasi, otonomi keilmuan dan manajemen; (4) Meningkatkan kualitas lembaga pendidikan yang diselenggarakan baik oleh masyarakat maupun pemerintah untuk memantapkan sistem pendidikan yang efektif dan efisien dalam menghadapi perkembangan ilmu pengetahuan, teknologi, dan seni serta dalam rangka menyongsong globalisasi yang menghadapkan pendidikan nasional dengan pendidikan di negara-negara lain; (5) Meningkatkan mutu dan kualitas lembaga pendidikan serta pendidik dan tenaga pendidikannya beserta sarana dan prasarananya melalui penetapan berbagai standar pendidikan; (6) Meningkatkan profesionalisme tenaga pendidik (guru dan dosen) dengan memberikan fasilitas yang memadai baik sarana dan prasarana maupun kesempatan untuk melanjutkan pendidikan pada jenjang yang lebih tinggi demi peningkatan kualitas mereka. Kebijakan ini juga disertai dengan kebijakan pemberian tunjangan profesi bagi guru dan dosen yang cukup memberikan tambahan motivasi dalam melaksanakan tugas mereka serta memberikan harapan besar untuk menambah kesejahteraan mereka (Marzuki, 2012).

\section{Otonomi Daerah dalam Bidang Pendidikan}

Undang-Undang No.23 Tahun 2014 Bab IV Pasal 9 ayat 1 menyebutkan tentang Pembagian Urusan Pendidikan Antara 
Pemerintah Pusat dengan Daerah bahwa "Urusan Pemerintahan terdiri atas urusan pemerintahan absolut, urusan pemerintahan konkuren, dan urusan pemerintahan umum". Urusan pemerintahan absolut yaitu urusan pemerintahan yang sepenuhnya menjadi kewenangan pemerintah pusat. Sedangkan urusan pemerintahan konkuren adalah urusan pemerintahan yang dibagi antara pemerintah pusat dengan pemerintahan daerah provinsi/ kabupaten/ kota, yang sekaligus juga menjadi dasar bagi pelaksanaan otonomi daerah. Sementara, urusan pemerintahan umum adalah urusan pemerintahan yang menjadi kewenangan Presiden sebagai kepala pemerintahan. Pada pasal 12 ayat 1 disebutkan pendidikan merupakan salah satu urusan pemerintahan wajib, terkait dengan Pelayanan Dasar yakni pelayanan publik untuk memenuhi kebutuhan dasar warga negara .

Pada era otonomi daerah kualitas pendidikan sangat ditentukan oleh kebijakan masing-masing pemerintah daerah, dikarenakan urusan administrasi oleh pemerintah pusat sudah diserahkan kepada pemerintah daerah. Kemajuan dan peningkatan mutu pendidikan sangat bergantung kepada program dari masing-masing pemerintah daerah. Bagi kepala daerah yang memiliki political will yang baik dan kuat dalam memajukan pendidikan maka daerah tersebut pendidikan akan berkembang dengan pesat, sebaliknya bagi pemerintah daerah yang political will buruk, visi dan misinya kurang berpihak pada kemajuan pendidikan maka dapat dipastikan daerah tersebut akan mengalami masa stagnasi atau kurang berkembangnya pendidikan. Otonomi daerah menurut Undang-undang SISDIKNAS no 20 tahun 2003 Pasal 8 disebutkan bahwa masyarakat berhak berperan serta dalam perencanaan, pelaksanaan, pengawasan, dan evaluasi program pendidikan. Pasal 9 juga menyebutkan masyarakat berkewajiban memberikan dukungan sumber daya dalam penyelenggaraan pendidikan.

Ada dua implikasi dari pelaksanaan otonomi daerah dalam dunia pendidikan yaitu:

(1) Penyelenggaraan pendidikan oleh pemerintah daerah, dampak penyelenggaraan pendidikan oleh pemerintah daerah adalah penyaluran anggaran pendidikan melalui pemerintah daerah, pengelolaan lembaga pendidikan oleh daerah, dan pengelolaan tenaga pendidik dan tenaga kependidikan oleh pemerintah daaerah; (2) Memberlakuan kurikulum berbasis sekolah (KTSP), pemerintah pusat memberikan sebagian besar kewenangan pengembangan kurikulum kepada masing-masing lembaga pendidikan, dan tetap mengacu pada UU No. 20 Tahun 2003 tentang SISDIKNAS dan Peraturan Pemerintah tentang Standar Nasional Pendidikan. Pemerintah pusat membuat model kurikulum KTSP dan menentukan standar kompetensi dari berbagi mata pelajaran, selebihnya masing-masing lembaga pendidikan harus mengembangkan pelajaran sesuai dengan kompetensi yang di harapkan, menambahkan kurikulum muatan lokal dan menambahkan pengalaman belajar peserta didik dengan kurikulum ke khasan sekolah.

Ujian nasional, dalam penerapan dan pelaksanaan masih menuai pro dan kontra. Bagi yang pro Ujian Nasional di buat untuk pemetaan kualitas pendidikan yang ada di Indonesia. Bagi yang kontra Ujian nasional sangat membebani siswa dalam belajar, ujian nasional dijadikan alat untuk memfonis kelulusan siswa, padahal banyak hal yang harus dikoreksi agar pendidikan di negeri ini tidak semakin terpuruk, hendaknya diikuti dengan perilaku yang terpuji dari semua pihak untuk menunjukkan kredibilitas ujian nasional seperti: tidak korupsi, manipulasi anggaran, dan kecurangan yang lain.

Sistem pendidikan di Amerika Serikat memungkinkan program manajemen berbasis sekolah yang bersifat kolaborasi antara kepala sekolah, dan guru dengan memberikan peran penting kepada orang tua dan komunitas lainya. Banyak pendidik yang mempromosikan keterlibatan orang tua. Keterlibatan orang tua menjadi alasan mendasar karena mampu meningkatkan nilai hasil ujian siswa yang lebih tinggi, nilai yang lebih baik dan meningkatkan sikap terhadap pembelajaran walaupun demikian tidak semua orang tua memanfaatkan sepenuhnya peluang yang ada untuk melibatkan diri dengan sekolah anak-anak mereka. Meskipun kurangnya partisipasi orang tua, tekanan reformasi telah menghasilkan pengaturan formal yang memberi orang tua dan komunitas lainya dalam mengambil 
keputusan lokal. Kelompok masyarakat dapat memberi saran dan bantuan dalam bidang: (1) Identifikasi tujuan, prioritas, dan kebutuhan; (2) Pemilihan dan evaluasi guru dan kepala sekolah; (3) Pembangunan kurikulum dan program ekstrakurikuler; (4) Dukungan untuk pembiayaan, (5) Perekrutan sukarelawan; dan (6) Bantuan untuk siswa di sekolah.

\section{Realitas Politik Pendidikan}

Dalam rancangan pembangunan jangka menengah (2005-2009) yang dituangkan dalam Peraturan Presiden RI No. 7 Tahun 2005, secara logis seharusnya rencana pembangunan jangka menengah tersebut di jabarkan dalam UU jangka panjang, akan tetapi baru rancangan Undang-undang Rencana Pembangunan Jangka Panjang (2005-2025) yang disusun oleh pemerintah. Sampai sekarang RUU tersebut belum berhasil di sepakati oleh DPR dalam bentuk undangundang (Tilaar, 2006).

Pemerintah dalam kurun waktu 5 tahun terakhir ini memberikan perhatian yang sangat besar terhadap kemajuan pendidikan. Pemerintah berupaya terus menerus menguatkan pembangunan pendidikan dalam rangka mencapai tujuan pendidikan nasional. walaupun pada kenyataan dan komitmen pemerintah yang masih rendah terhadap pemenuhan angka $20 \%$ anggaran pendidikan artinya pemenuhan angka tersebut belum bisa dijalankan sekaligus. Hal tersebut bukan karena pertimbangan finansial semata, akan tetapi berdasarkan penilaian di lapangan yang bersifat teknis pada Departemen Pendidikan Nasional dan Departemen Agama untuk melaksanakan pendidikan yang bermutu dan relevan dengan kebutuhan daerah dalam rangka pembangunan negara Indonesia yang bersatu (Tilaar, 2006).

Sampai hari ini dunia pendidikan di negara ini masih dihadapkan dengan berbagai macam tantangan. Tantangan utama yang dihadapi dunia pendidikan pada saat ini adalah : (1) Peningkatan akses; (2) Pemerataan kualitas pendidikan; (3) Kualitas layanan pendidikan; (4) Perbaikan kurikulum pendidikan; (5)Tuntutan profesionalisme dan (6) kesejahteraan guru.

Pemerintah telah menyediakan anggaran pendidikan melalui Bantuan Operasional
Sekolah (BOS) untuk jenjang pendidikan dasar, namun pada kenyataanya ada dbeberapa sekolah yang masih melakukan pungutan sehingga sangat memberatkan para orang tua dari keluarga pra sejahtera atau keluarga miskin. Semakin kesini semakin mencolok kesenjangan partisipasi pendidikan terutama pada pendidikan menengah dan perguruan tinggi.

Beberapa kebijakan pemerintah yang perlu menjadi perhatian sebagai dasar pengambilan keputusan politik dalam pendidikan di masa datang adalah: (1) Menghapus dikotomi dualisme penyelenggaraan pendidikan, tidak adanya diskriminasi antara pendidikan yang berada di bawah naungan Departemen Pendidikan Nasional dan Departemen Pendidikan Agama. Berjalan seimbang dalam hal mutu, kualitas dan kemajuannya; (2) Merealisasikan anggaran pendidikan sebesar $20 \%$ dari APBN dan APBD jika pemerintah serius untuk mencerdaskan kehidupan anak bangsa. Pembebasan biaya pendidikan sekolah pada jenjang pendidikan dasar sebagaimana amanat UUD 1945 Pasal 31 ayat 2 "Setiap warga negara wajib mengikuti pendidikan dasar dan pemerintah wajib membiayai". Perbaikan kurikulum untuk membentuk insan Indonesia yang cerdas, beriman dan bertaqwa, berakhlak mulia, dan mengembangkan potensi dirinya. Penghargaan pada pendidik dengan peningkatan kualifikasi, profesionalisme dan kesejahteraan guru.

\section{KESIMPULAN}

Adanya landasan yuridis-politis menjadi pedoman penyelenggaraan pendidikan. Landasan yuridis-politis pendidikan tertuang dalam undang-undang dan peraturan menteri, berikut adalah undang-undang penyelengaraan pendidikan di Indonesia yakni Undang-Undang RI Nomor 20 Tahun 2003 tentang Sistem Pendidikan Nasional, Undang-Undang No. 14 Tahun 2005 tentang Guru dan Dosen, UndangUndang No. 19 Tahun 2005 tentang Standar Nasional Pendidikan. Sebagai dasar pelaksanaan pendidikan Indonesia yang terjabarkan dalam pasal-pasal tentang tujuan dan kebijakan yang harus dilakukan oleh penyelenggara pendidikan dari tingkat pusat hingga tingkat satuan Pendidikan (Undang- 
undang Republik Indonesia Nomor 14 Tahun 2005 tentang Guru dan Dosen, n.d.) (UndangUndang No. 19 Tahun 2005 Tentang Standar Nasional Pendidikan, n.d.).

Adanya landasan yuridis-politis juga memperkuat sistem pendidikan yang diselenggarakan di tingkat satuan pendidikan. Landasan yuridis-politis menjadi dasar bagi terselenggaranya pendidikan yang sesuai dengan tujuan pendidikan nasional yakni mencerdaskan kehidupan bangsa. Beberapa kebijakan yang telah dilakukan oleh pemerintah di bidang pendidikan yakni: 1) menghapus dikotomi dualisme penyelenggaraan pendidikan, tidak adanya diskriminasi antara pendidikan yang berada di bawah naungan Departemen Pendidikan Nasional dan Departemen Agama, berjalan seimbang dalam hal mutu, kualitas dan kemajuannya; 2) Merealisasikan anggaran pendidikan sebesar $20 \%$ dari APBN dan APBD. Jika pemerintah serius untuk mencerdaskan kehidupan anak bangsa, pembebasan biaya pendidikan Sekolah pada jenjang pendidikan dasar sebagaimana amanat UUD 1945 Pasal 31 ayat 2 "Setiap warga negara wajib mengikuti pendidikan dasar dan pemerintah wajib membiayai"; 3) Perbaikan kurikulum untuk membentuk insan Indonesia yang cerdas, beriman dan bertaqwa, berakhlak mulia, dan mengembangkan potensi dirinya; 4) Penghargaan pada pendidik dengan peningkatan kualifikasi, profesionalisme dan kesejahteraan guru.

Berdasarkan pembahasan di atas, landasan yuridis-politis memiliki peranan yang penting dalam penyelenggaraan pendidikan. Landasan yuridis-politis menjadi dasar hukum bagi lahirnya kebijakan-kebijakan di bidang pendidikan. Kebijakan-kebijakan yang diharapkan akan meningkatkan kualitas pendidikan di Indonesia ditinjau dari aspek tata kelola pendidikan. Landasan yuridis-politis juga menjadi fondasi yang kuat dalam sistem pendidikan di tingkat satuan pendidikan sebagai penyelenggara pendidikan, karena di dalam kebijakan, peraturan, dan undangundang yang ada berisi tentang arahan yang akan dilakukan oleh penyelenggara pendidikan dalam upaya mencapai tujuan pendidikan nasional.

\section{REFERENSI}

Aliansar, D. (2008). Bahan Ajar Pedagogik. Padang: Universitas Negeri Padang.

Lebe, E. F. (2015). Landasan Legalitas Dan Politis Pendidikan. Retrieved from http://eduarduslebe.blogspot.com/2015/11 /landasan-legalitas-dan-politis.html

Lestari, I., \& Rahmawati. (2012). Problematika Kesenjangan Pendidikan. Retrieved from https://rahmawatiindahlestari.wordpress.c om/semester-1/lkpp/landasan-hukumpendidikan

Marzuki. (2012). Politik Pendidikan Nasional Dalam Bingkai Undang-Undang Sistem Pendidikan Nasional. Jurnal Penelitian Humaniora, 17(2).

Tilaar, H. A. . (2006). Standarisasi Pendidikan Nasional. Suatu Tinjauan Kritis. Jakarta: Rineka Cipta.

Undang-Undang Dasar Negara Republik Indonesia Tahun 1945.

Undang-Undang No. 19 Tahun 2005 Tentang Standar Nasional Pendidikan.

Undang-undang Republik Indonesia Nomor 14 Tahun 2005 tentang Guru dan Dosen. 